\title{
ПОЛЬСЬКО-УКРӒ̈НСЬКИЙ ОБМІН ДОСВІДОМ НАДАННЯ ПСИХОЛОГІЧНОЇ ПІДТРИМКИ ЛІТНІМ ЛЮДЯМ У ПЕРІОД КАРАНТИНУ
}

https://doi.org/10.37472/2707-305X-2021-3-2-15-1

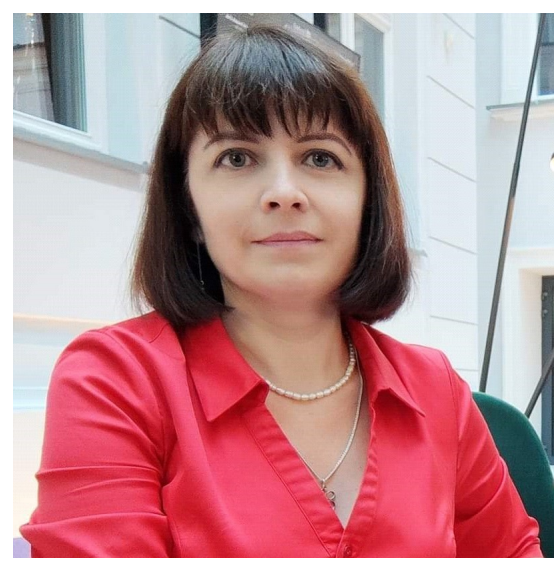

Людмила Миколаївна ДЯЧЕНКО кандидат педагогічних наук, старший науковий співробітник відділу зарубіжних систем педагогічної освіти і освіти дорослих Iнституту педагогічної освіти і освіти дорослих імені Івана Зязюна Національної академії педагогічних наук України, м. Київ, Україна

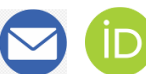

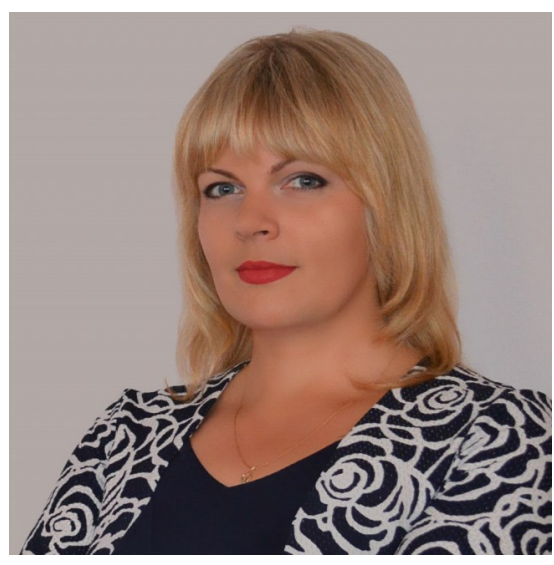

Анотація. Висвітлено мету поїдки до Польщі виконавців проєкту «Психологічна підтримка літніх осіб у період карантину». Подано зміст основних зустрічей у межах поїздки. Зустрічі відбувалися з представниками Педагогічного університету в Кракові, Академії спеиіальної педагогіки імені Марії Гжегожевської у Варшаві, Радою сеньйорів (Краків), повноважним представником мера Кракова з питань сім'ї, працівниками будинку соціальної допомоги, Спільнотою мешканців житлово-будівельного кооперативу "Остобрамська» та ії наглядовою радою (Варшава) тощо. Зроблені ключові висновки щодо особливостей психологічної підтримки літніх осіб у Польщі.

Ключові слова: літній вік; психологічна підтримка; карантин.

Пандемія коронавірусу COVID-19, яка за два з половиною місяці поширилася на всі континенти, стала перевіркою людства на здатність протидіяти загальноцивілізаційним загрозам, організовуватися для розв'язання нагальних проблем і пошуку ефективних методів виходу зі складних ситуацій. За таких умов кожен з нас зустрівся з низкою проблем та негативними емоціями, які їх супроводжують. Зокрема, в умовах пандемії ми опинилися в ситуації невизначеності, яка $€$ доволі стресовою. Карантинні обмеження внесли в наше життя багато змін, до яких доводилося швидко адаптуватись.

Обмежувальні заходи вплинули на всіх громадян України, та однією з найбільш вразливих верств населення стали особи літнього віку. Окрім загрози життю і здоров'ю, вони зустрілися із соціально-економічними проблемами. Такі звичні справи, як покупка продуктів, отримання пенсії або оплата комунальних послуг перетворилися для деяких людей у складну процедуру, виконання якої залежить від якості роботи відповід- 
них служб. Іншими проблемами, з якими літні люди опинилися сам на сам, $\epsilon$ емоційнопсихологічні. У період карантину різко скоротилася кількість соціальних контактів, зросли почуття самотності та невизначеності, єдиними засобом спілкування стали телефон та інтернет. Виявилося, що останнім уміють користуватися не всі люди літнього віку. Тому однією з ініціатив Інституту педагогічної освіти і освіти дорослих імені Івана Зязюна НАПН України став проєкт «Психологічна підтримка літніх осіб у період карантину», переможець конкурсу з виконання наукових досліджень і розробок «Наука для безпеки людини та суспільства» у 2020 році від Національного фонду досліджень України (реєстраційний номер проєкту 2020.01/0221).

У рамках проєкту вже підготовлено брошуру, буклети, радіопередачі, відеоролики, вебінари, зміст яких допомагає літнім людям знайти способи самодопомоги, а їхнім близьким та рідним виявити особливості взаємодії та визначити методи їхньої психологічної підтримки. Важливого значення набуває поєднання зусиль громадян нашої країни: науковців і практиків, медиків і психологів, соціальних працівників та членів родин.

Водночас пандемія COVID-19 не має кордонів і охопила 80 \% країн світу, тому для більш швидкого ії подолання країни повинні працювати разом, зокрема координувати свої зусилля та вчитися одна в одної. Саме для цього виконавці проєкту «Психологічна підтримка літніх осіб у період карантину» у складі О.Г. Коваленко, Л.Б. Лук'янової, Е.О. Помиткіна, Л.М. Дяченко, О.В. Іванової, Т.Г. Кравцової здійснили десятиденну освітню поїздку до Польщі за підтримки Національного фонду досліджень України. Ії̈ метою було вивчення досвіду польських колег з об'єднання зусиль громадян в умовах пандемії та надання психологічної підтримки літнім людям у цей період.

Кожен із днів був насичений зустрічами, обговореннями проблем літніх людей в Польщі й Україні та обміном досвідом.

Фахівцями, які найчастіше взаємодіють 3 людьми літнього віку, зокрема надають їм психологічну підтримку, є соціальні працівники. Виявлення особливостей їхньої професійної підготовки в Польщі відбувалося під час зустрічей з ректором Педагогічного університету в Кракові, доктором хабілітованим, професором Пьотром Бореком (Piotr Borek), деканом відділу педагогіки і психології, доктором хабілітованим, професором

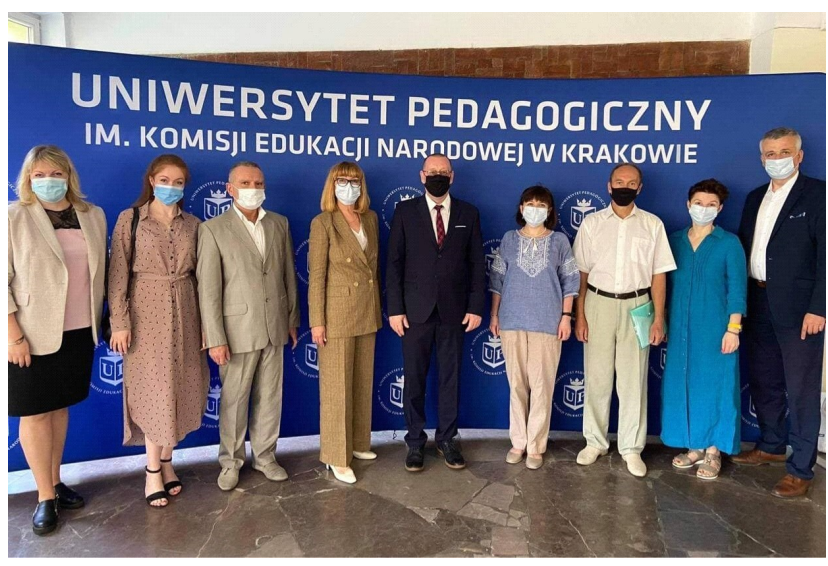

Зустріч виконавців Проєкту з ректором Педагогічного університету в Кракові, доктором хабілітованим, професором Пьотром Бореком (Piotr Borek), деканом відділу педагогіки і психології, доктором хабілітованим, професором Іренеушем Швіталою (Ireneusz Świtała), директором Інституту соціальної роботи, доктором хабілітованим, професором Норбертом Г. Пікулою (Norbert G. Pikuła)

Іренеушем Швіталою (Ireneusz Świtała), директором Інституту соціальної роботи, доктором хабілітованим, професором Норбертом Г. Пікулою (Norbert G. Pikuła) та його заступником, доктором гуманістичних наук Кшиштофом Хачком (Krzysztof Chaczko).

Серед особливостей професійної підготовки та професійного розвитку соціальних працівників виділено такі:

- Принцип міждисциплінарності є визначальним у структуруванні освітніх програм з підготовки соціальних працівників. Відповідно теми модулів є комплексними і мають на меті розгляд тих чи інших явищ і процесів соціальної роботи у площині різних наук у їхній нерозривній єдності. Модулі передбачають оволодіння компетентностями, основою яких $є$ теоретичні знання із соціології,

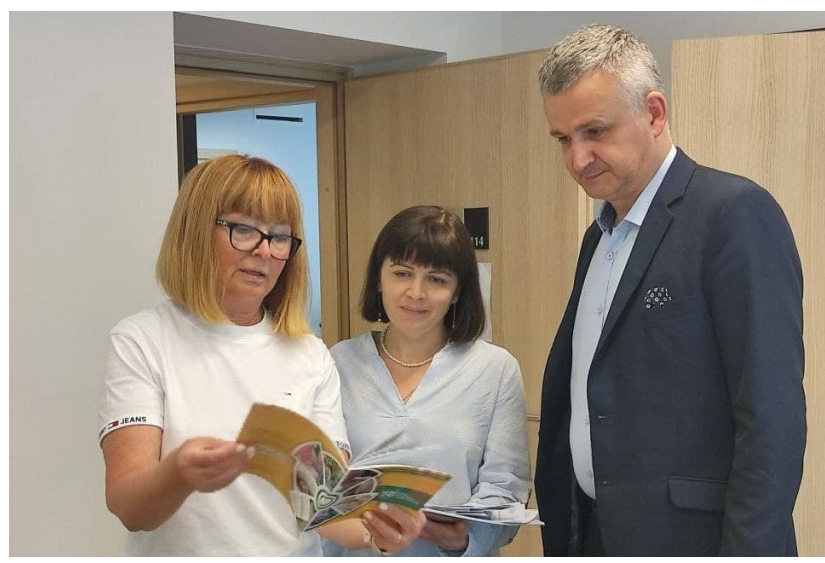

Виконавці Проєкту Л.Б. Лук'янова, О.Г. Коваленко розповідають про Проєкт директору Інституту соціальної роботи, доктору хабілітованому, професору Норберту Г. Пікулі (Norbert G. Pikuła) 
соціальної педагогіки, соціальної політики, соціальної медицини та реабілітації, психології, права, менеджменту тощо.

- Практична підготовка майбутніх соціальних працівників ґрунтується на теорії навчання через досвід. Виробнича практика студентів займає не менше 30 \% навчального часу. У цьому контексті важливо підкреслити, що питання інтеграції теорії і практики перебуває в центрі уваги.

- Теоретична підготовка в університеті має практичну спрямованість і здійснюється з використанням методів кооперативного, проблемного, ситуаційного, дослідного навчання та рефлексії.

- Значна увага приділяється індивідуальному супроводу студентів під час навчання в університеті та практики у формі наставництва (менторства) з використанням методу коучингу.

Подальше з'ясування особливостей і проблем професійного розвитку соціальних працівників у Польщі відбувалося в Академії спеціальної педагогіки імені Марії ґжегожевської (Варшава). 3 вітальним словом до членів делегації з України звернулася пані ректор, доктор хабілітований, професор Барбара Марчінковска (Barbara Marcinkowska). Пані ректор означила місію університету та презентувала напрями підготовки фахівців для роботи з дітьми, підлітками, молоддю та дорослими з особливостями інтелектуального й фізичного розвитку, емоційної та мотиваційноповедінкової сфер особистості. Українською делегацією у Варшаві опікувалися пан професор Франчішек Шльосек (Franciszek Szlosek), доктор хабілітований, голова Міжнародного наукового товариства «Польща - Україна», та пан професор Ян Сікора, доктор хабілітований, професор кафедри педагогіки праці й андрагогіки Академії спеціальної педагогіки імені Марії ґжегожевської.

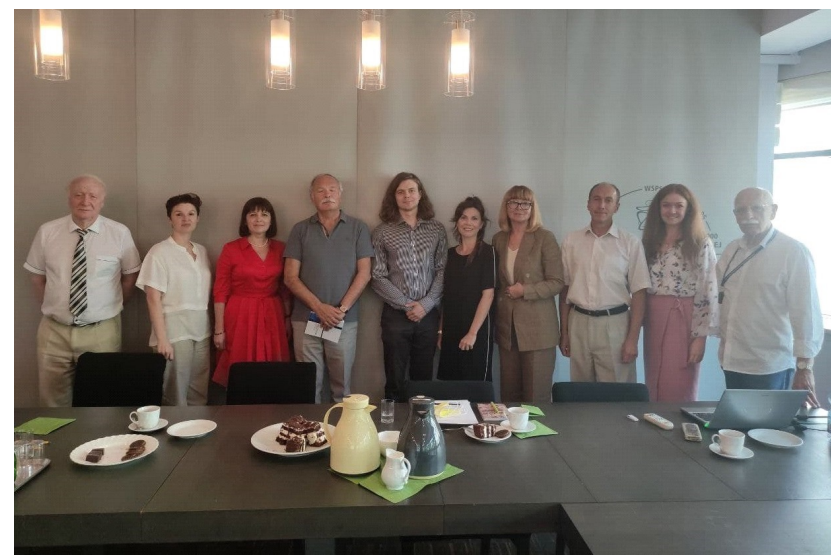

Зустріч виконавців Проєкту в Академії спеціальної педагогіки імені Марії Ґжегожевської
Вони зазначили, що випускники університету працюють у школах, центрах спеціальної освіти, центрах соціально-психологічної реабілітації, центрах соціальних служб для сім'ї, дітей та молоді й інших установах, які надають соціальні та психологічні послуги громадянам.

Під час обговорення проблем професійного розвитку соціальних працівників Агнєшка Кос (Agnieszka Kos), асистентка кафедри соціальної політики та соціальної роботи Інституту соціальної профілактики та соціальної роботи, зазначила, що безпосередньо у своїй роботі ці фахівці здійснюють активний пошук шляхів розв'язання нагальних соціальних проблем. Відповідно професіоналів для соціальної сфери потрібно готувати так, щоб вони були здатні коригувати, змінювати чи усувати негативні соціальні прояви у суспільстві. Натомість вони щоденно зустрічаються з невизнанням їхніх зусиль суспільством, низьким соціальним статусом професії, завищеними очікуваннями підопічних осіб, відсутністю можливості отримати супервізійний супровід, який насамперед $€$ методом підтримки і тільки потім - професійного зростання.

Щоб якісно виконувати свої професійні обов'язки, соціальний працівник має бути обізнаним 3 реальними проблемами осіб, з якими він взаємодіє. Виявляти реальні потреби та запити людей літнього віку допомагають Ради сеньйорів. Рада сеньйорів - це муніципальна рада літніх людей, тобто орган місцевого самоврядування, що представляє і захищає інтереси жителів, яким більше ніж 60 років, перед владою міста чи іншого населеного пункту.

Одна із зустрічей учасників проєкту відбулась із головою Ради сеньйорів у Кракові Антоні Вятром (Antoni Wiatr) та секретарем Ради Вєславою

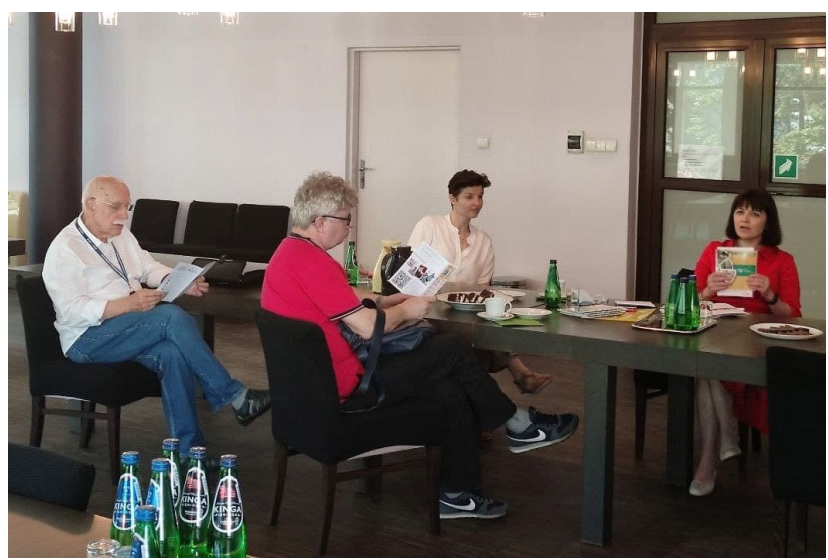

Виконавець Проєкту (О.Г. Коваленко) розповідає про Проєкт в Академії спеціальної педагогіки імені Марії ґжегожевської 


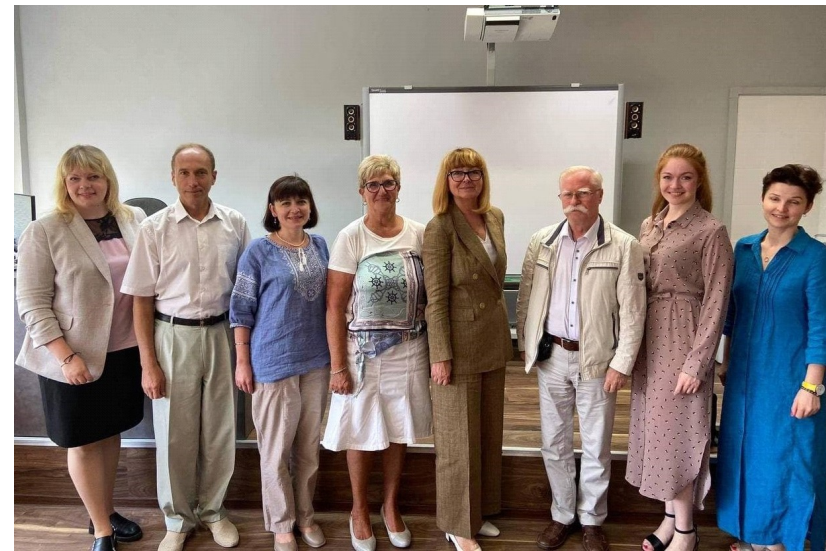

Зустріч виконавців Проєкту з головою Ради сеньйорів у Кракові Антоні Вятром (Antoni Wiatr) та секретарем Ради Вєславою Зборох (Wiesława Zboroch)

3борох (Wiesława Zboroch). Вони розповіли членам української делегації про потреби літніх людей та проблеми, з якими вони зіткнулися під час пандемії та карантинних обмежень. Серед найбільш поширених проблем вони назвали такі: недостатня поінформованість літніх людей щодо дій у випадку погіршення здоров'я під час карантину; неможливість задоволення потреби у спілкуванні в умовах самоізоляції; недостатні вміння користуватися комп'ютерною технікою та мобільними додатками; неспроможність розпізнати шахрайство в інтернеті та з використанням телефону протистояти йому.

Наскільки міська влада Кракова прислухалася до рекомендацій Ради сеньйорів та які заходи здійснила для задоволення потреб літніх людей у період карантину? Пошук відповідей на ці та інші питання відбувався під час зустрічі з повноважним представником мера Кракова з питань сім'ї пані Маженою Пашкот (Marzena Paszkot). Вона познайомилася 3 результатами українського проєкту «Психологічна підтримка літніх осіб у пе-

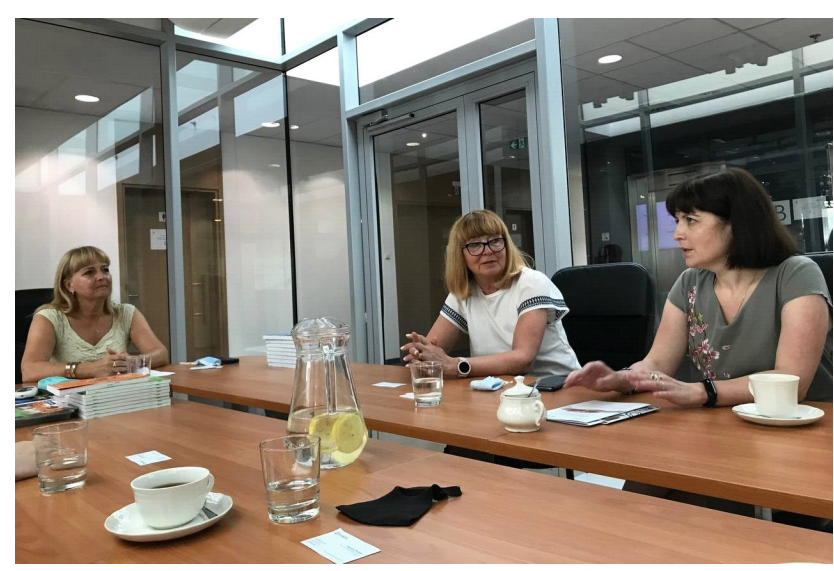

Зустріч виконавців Проєкту з повноважним представником мера Кракова з питань сім'ї пані Маженою Пашкот (Marzena Paszkot) ріод карантину» та розповіла про соціальні проєкти у місті Кракові, метою яких є підтримка багатодітних сімей, людей з інвалідністю, а також осіб літнього віку.

Відповідаючи на запитання щодо заходів 3 надання психологічної підтримки літнім людям у Кракові, пані Мажена Пашкот розповіла про створення телефону довіри та пунктів психологічного консультування, які діяли у період карантину. У телефонному режимі кожен із жителів міста міг отримати необхідну інформацію щодо дій у випадку погіршення здоров'я під час карантину. Водночас психологи-консультанти надавали необхідні рекомендації членам родин та особам літнього віку щодо методів емоційної регуляції в умовах стресу, пов'язаного з пандемією. Тим особам літнього віку, для яких важливе значення має особистий контакт у спілкуванні, психологи надавали індивідуальні послуги у спеціальних консультативних пунктах за попереднім записом, щоб уникнути великого скупчення людей. Ці консультативні пункти розташували у різних районах міста, щоб кожна літня людина обрала найближчий до свого дому і найзручніший для себе.

Також пані Мажена Пашкот представила членам української делегації «Інформатор краківського сеньйора». Це путівник для літніх мешканців міста Кракова, у якому розміщено інформацію та поради з різних питань, наприклад: як цікаво та креативно жити в Кракові; як допомогти собі та іншим зберегти й покращити здоров'я та добробут; де шукати допомогу; як реагувати у надзвичайних ситуаціях; як досягти соціальних цілей та сприяти розвитку місцевого середовища та ін. «Інформатор краківського сеньйора» - це один з чотирьох путівників-порадників, у яких представлено проєкти й послуги, що реалізуються у Кракові для покращення якості життя містян. Інші видання путівників присвячено вирішенню проблем молоді, людей з інвалідністю та багатодітних сімей.

Взаємодіючи з людьми літнього віку, варто пам'ятати про їхні вікові особливості та емоційні зміни. Ці питання стали ключовими у розмові $з$ директоркою Районного центру допомоги родинам в Тарнуві Анною Гурскою (Anna Górska). Вона зазначила, що одна з головних психологічних особливостей людей у літньому віці - почуття самотності. На жаль, для цього часто $є$ об'єктивні причини - брак спілкування, неувага з боку близьких, неможливість дотримуватися звичного способу життя та ін. Водночас почуття самотності 
може завдати людині душевної травми й викликати негативні емоції.

Ще одна особливість, за словами пані Анни Гурскої, полягає в тому, що літнім людям зазвичай важко адаптуватися до нових обставин. Багато з них асоціюють старість з немічністю. Ці думки особливо посилились у період карантину і, як наслідок, літня людина починає занурюватися в негативні думки, ії охоплюють негативні емоції щодо своєї безпорадності. Тому Районний центр допомоги родинам в Тарнуві започаткував освітні ініціативи розвитку вмінь літніх осіб користуватися комп'ютерною технікою та мобільними додатками, щоб кожен з них мав можливість самостійно оплачувати комунальні послуги, замовляти їжу чи ліки через інтернет. У той же час фахівці центру створили просвітницькі програми для літніх людей щодо протистояння шахрайству через телефон та інтернет (особливо у соціальних мережах).

Щоб літні люди не почувалися самотніми, працівники центру організовують зустрічі на свіжому повітрі, де кожен може знайти активність відповідно до своїх уподобань: гра в шахи чи бадмінтон, виготовлення виробів з дерева чи з тканини, майстер-класи з кулінарії чи рукоділля.

Для самотніх людей, поруч з якими немає рідних та близьких, є «будинки соціальної допомоги». Учасники української делегації відвідали один з них, розташований у місті Конти повіту Мінського Мазовецького воєводства. У зустрічі взяв участь заступник голови правління повіту Мінського Вітольд Стефан Кікольскі (Witold Stefan Kikolski). Він розповів про досягнення та труднощі реалізації завдань соціальної допомоги на прикладі територіальної громади міста Сєнніца повіту Мінського. Рената Малецка (Renata Małecka), директор Повітового центру підтримки сім'ї в Мін-

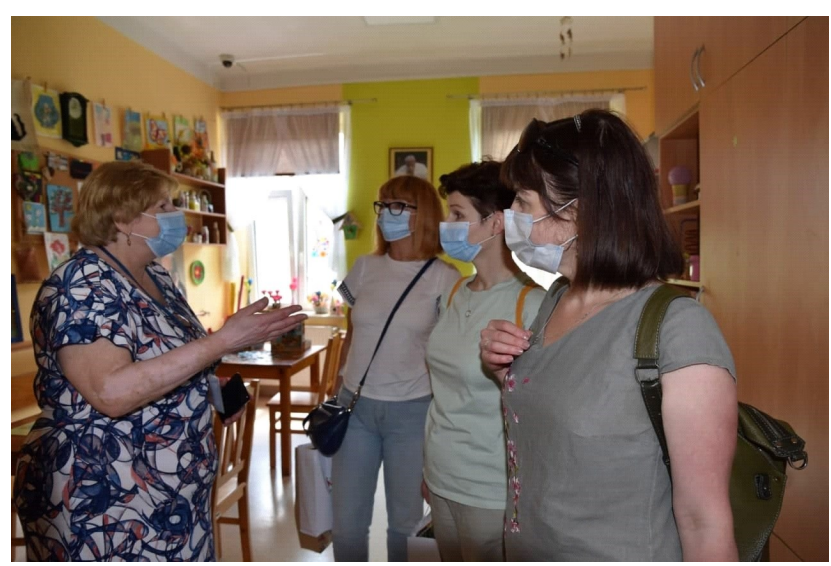

Відвідування виконавцями Проєкту будинку соціальної допомоги у місті Конти повіту Мінського Мазовецького воєводства
ську-Мазовецькому, познайомила учасників зустрічі з особливостями організації соціальної і психологічної підтримки літніх людей у повіті Мінському. Моніка Вільк (Monika Wilk), директор Tериторіального центру соціального обслуговування в місті Сєнніца, охарактеризувала особливості взаємодії з людьми літнього віку та означила труднощі, з якими зустрілися люди цього віку та соціальні працівники в умовах карантину.

Одне з питань, яке постало під час обговорень що ми розуміємо під поняттям «старіння». Воно буває фізичним (хвороби, старіння організму), соціальним (вихід на пенсію і, як результат, звуження кола спілкування, втрата рідних людей, друзів), психологічним (втрата інтересу до навколишнього світу, до інших людей, небажання розвиватися). Виходячи з цього, польські колеги зазначили, що фізичне та соціальне старіння зупинити неможливо, а от запобігти психологічному можна і потрібно. Саме про це йдеться, коли говорять: «Варто залишатися молодим душею».

Працівники «будинку соціальної допомоги» у місті Конти означили пункти, що їх дотримуються у роботі з людьми літнього віку, як-от:

- не дозволяти літній людині замикатися в собі, але в той же час не нав'язувати своє спілкування, якщо зараз людина цього не хоче;

- знайти для літньої людини цікаве заняття, підтримувати їі інтерес до хобі, якщо таке $є$;

- сприяти тому, щоб літні люди більше гуляли на свіжому повітрі, тривале перебування в одному приміщенні не додає позитивних емоцій.

За підсумками обговорень учасники зустрічі дійшли висновку, що система соціального захисту населення буде ефективно діяти не лише за умови підвищення фахового рівня соціальних працівників, а й за умови безпосередньої активності та небайдужості самих громадян на рівні села, селища, міста, територіальної громади.

Яскравий приклад небайдужості сусідів до людей літнього віку члени української делегації побачили у Варшаві. У цьому місті була нагода познайомились із діяльністю Спільноти мешканців житлово-будівельного кооперативу «Остобрамська» та їі наглядової ради. Таку спільноту створено 24 червня 2004 р. та зареєстровано у Національному судовому реєстрі Польщі. До житлового кооперативу належать будинки на чотирьох вулицях. Перші з них введено в експлуатацію у 1978 р. На сьогодні до цього кооперативу належать 32 житлові будинки, загальна кількість квартир - 4182. Мета об'єднання мешканців у жит- 


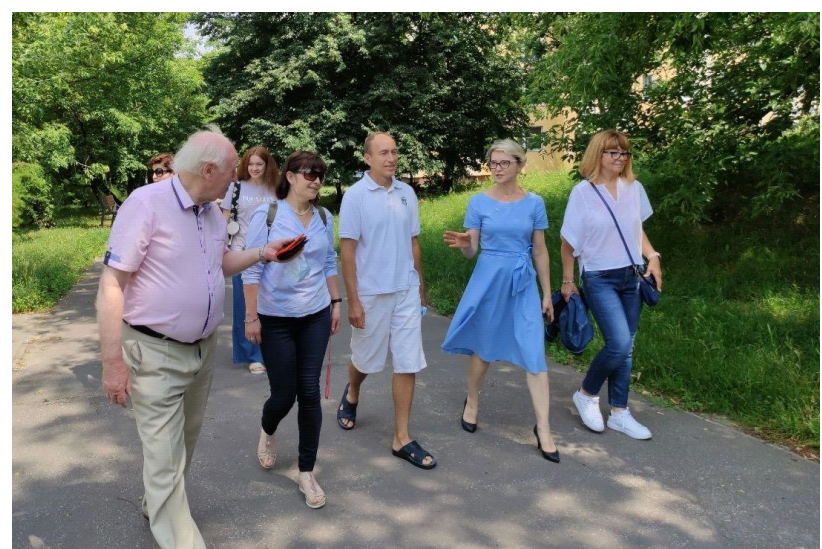

Ознайомлення виконавців Проєкту із діяльністю Спільноти мешканців житлово-будівельного кооперативу «Остобрамська»

ловий кооператив - забезпечити створення належних умов для життя та відпочинку на його території.

Голова ради Спільноти мешканців Даріуш Куява (Dariusz Kujawa) представив цілі та завдання спільноти й розкрив порядок узгодження рішень щодо таких питань: облаштування прибудинкової території, реконструкція фасадів будинків, ремонтування приміщень спільного користування, оновлення ліфтів та інше. Заступниця голови ради 3 фінансово-організаційних питань Спільноти мешканців Йоланта Жєліньска (Jolanta Zielińska) розповіла про порядок збору внесків, способи залучення додаткових коштів у співпраці з представниками малого бізнесу та благодійних фондів, означила пріоритетні напрями фінансування та форми звітності перед мешканцями щодо використання їхніх коштів. Голова спостережної ради Спільноти мешканців Лех Адамчак (Lech Adamczak) презентував роботу культурноосвітнього клубу «Релакс», який створений на території житлового кооперативу для задоволення культурних та освітніх потреб мешканців. Більш детально він розповів про заходи клубу, організовані для підтримки осіб літнього віку та способи їх залучення до активної творчої, освітньої і волонтерської діяльності.

Цікавим досвідом цієї спільноти є ініціатива «Телефонний друг», коли мешканці будинків домовлялись, хто й кому з літніх людей буде телефонувати, щоб поцікавитися самопочуттям та потребами під час карантину чи просто поспілкуватись про приємні справи, поділитись приємними враженнями та емоціями.

Завдяки таким зустрічам учасники проєкту усвідомили значення об'єднавчої сили громади коли мешканці сусідніх будинків об'єднуються для обговорення нагальних проблем та разом шукають шляхи їх вирішення, зокрема для подолання труднощів, пов'язаних із пандемією та карантинними обмеженнями.

Десятиденний візит виконавців проєкту «Психологічна підтримка літніх осіб у період карантину» за підтримки Національного фонду досліджень України до Польщі дав змогу виявити спільні проблеми літніх людей у двох країнах, уточнити методи надання психологічної допомоги та знайти нові ідеї для подальшого розвитку проєкту в Україні. Багато вже зроблено - водночас багато ще попереду!

Ключові висновки щодо особливостей психологічної підтримки літніх осіб у Польщі, зроблені після ознайомлення з досвідом наших сусідів:

1) для подолання труднощів велике значення мають бажання й активність самої людини;

2) водночас людина літнього віку не завжди здатна самотужки впоратися з труднощами, тому важливо не бути байдужим один до одного й не боятися просити про підтримку та допомогу;

3) велике значення має об'єднання зусиль як родини, так і громади, бо почуття самотності часто негативно впливає на психіку;

4) в умовах тривалого карантину та вимушеної ізоляції літні люди дійсно потребують психологічної підтримки, а ії можна отримати від рідних, друзів, сусідів, фахівців (наприклад, психологів чи соціальних працівників);

5) важливо не мовчати, а говорити про те, якої саме допомоги ви потребуєте!

Отже, об'єднання зусиль і спільна діяльність допомагають долати проблеми, створювати комфортне середовище для життя та розвитку кожної особистості.

\section{СПИСОК ВИКОРИСТАНИХ ДЖЕРЕЛ}

Вік обраних. (n.d.). Головна [YouTube канал]. YouTube. https://www.youtube.com/channel/

UC9OOKHcTiqCOUFzPjYP-GDQ

Вік обраних [@project.ipood]. (n.d.). Дописи [Instagram Profile]. Instagram. https://www.instagram.com/ project.ipood/

Інститут педагогічної освіти і освіти дорослих імені Івана Зязюна НАПН України. (2020-2021). ПРОЕКТ Психологічна підтримка літніх осіб у період каранmuнy. http://ipood.com.ua/projects/

Коваленко, О.Г. (2020). Проєкт «Психологічна підтримка літніх осіб у період карантину». Вісник Начіональної академії педагогічних наук України, 2(2). https://doi.org/10.37472/2707-305X-2020-2-2-15-1

Психологічна підтримка літніх осіб. (n.d.). Головна [Facebook Page]. Facebook. https:// www.facebook.com/project.ipood 


\section{POLISH-UKRAINIAN EXCHANGE OF EXPERIENCE IN PROVIDING PSYCHOLOGICAL SUPPORT TO THE ELDERLY DURING QUARANTINE}

Olena Kovalenko

DSc in Psychology, Professor, Chief Research Fellow of the Department of Andragogy, Ivan Ziaziun Institute of Pedagogical and Adult Education of the National Academy of Educational Sciences of Ukraine, Kyiv, Ukraine Liudmyla Diachenko

PhD in Pedagogy, Senior Research Fellow of the Foreign Systems of Pedagogical and Adult Education Department, Ivan Ziaziun Institute of Pedagogical and Adult Education of the National Academy of Educational Sciences of Ukraine, Kyiv, Ukraine

Abstract. The purpose of the visit to Poland of the executors of the project "Psychological Support for the Elderly during Quarantine" is highlighted. The content of the main meetings within the trip is given. Meetings were held with representatives of the Pedagogical University in Krakow, Maria Grzegorzewska Academy of Special Pedagogy in Warsaw, Council of Seniors (Krakow), Krakow Mayor's Plenipotentiary for Family Affairs, employees of the Social Welfare House, Community of Housing Cooperatives and its cooperative supervisory board (Warsaw), etc. The key conclusions about the peculiarities of psychological support for the elderly in Poland are made.

Keywords: elderly; psychological support; quarantine. 